\title{
Ethical Issues in Genetic Engineering
}

\author{
by John V. Tunney
}

Any science which has within its potential the alteration or the modification of human genes has awesome implications. The political impact of these possibilities, however, might be just as powerful as the scientific impact.

Therefore, the issues raised by the biomedical sciences must be debated. The debate must begin now. If we postpone open discussion in this area, we might find irreversible trends not only in genetics but also in political freedoms. For, if the polity responds to the scientific community through fear and mistrust, it might delegate authority to a despot or a demogogue who appeals to the people with the promise of "curbing scientific abuses." If people are sufficiently frightened-if they feel they need to be rescued from a menace they do not understandthey are more likely to delegate freedoms and less likely to respond with restraint.

All segments of society should be involved in the debate which these new technologies demand. The techniques must be discussed and debated among lawyers, doctors, theologians, legislators, scientists, journalists, and all other segments of society. The issues raised require interdisciplinary attention.

The ethical questions raised by the possibilities implicit in genetic engineering are no less fundamental than the issucs of free choice, the quality of life, the community of man, and the future of man himself. Let me posit a list of ten general considerations suggesting possible ethical distinctions:

First, if we are to engage in any eugenics, negative or positive, we must confront three vital questions which pervade this entire subject: (a) What traits are to be considered desirable? (b) Who is to make that determination? (c) When in the course of human development will the choice be made? These questions cannot be underestimated in their importance to the future of man, particularly when we are considering biological alternatives which might not be reversible.

Second, we must ask whether the genetic engineering or "improvement" of man would affect the degree of diversity among men. Does it presume a concept of "optimum" man? Is diversity important as a goal in itself? Does-or should-man seek an "optimum" or does he seek a "unique"? What would the quest for an "optimum" do for our sense of tolerance of the imperfect? Is "tolerance" a value to be cherished?

Third, we should consider whether it might be appropriate to delineate different biological times or moments-at least in humans-during which experimentation might occur. Do different ethical considerations apply if we attempt to distinguish between experimentation on (a) an unfertilized sperm or egg; (b) a fertilized sperm or egg; (c) a fetus; (d) an infant; (e) a child, perhaps until it becomes an adult; (f) an adult-or at any particular moment during any of these stages? Might the factors to be balanced in making a decision as to whether experimentation is proper vary at different stages of human development?

Fourth, is there a workable diffcrence between "genetic therapy" (defined as therapy to correct genetic factors

"Ethical Issues in Genetic Engineering" is abstracted from Senator Tunney's speech to the genetic engineering conference at Caltech on May 6. The full speech was read into the Congressional Record on May 23. 
There are certain suggestions that I would offer in any debate on this subject: that among the values which man ought to protect most fully are those of freedom, of humility, of compassion, of diversity, and of skepticism; that any scientific or technical initiatives in one generation which would foreclose or eliminate the options of future generations smack of arrogance and should be avoided; that man should exercise the utmost caution in this sensitive field and that decisions which will be genetically irreversible might require a wisdom which we do not possess; that there is no reason why the ethics or morality of any one of us are better than those of another. Therefore, the issues raised by the biomedical sciences must be debated, and the debate must begin now. known to cause disease) and "genetic engineering" (defined as techniques to alter man in terms of some parameters other than disease)? Is it appropriate to attempt such a distinction in definitions in this emotionally charged area? Might the term "genctic therapy" evoke less reaction than the term "genetic engineering"? Or are such distinctions unworkable?

Fifth, it would seem advisable to ask whether a particular technique is devised for the therapeutic treatment of an individual-or whether it is dcsigned to have a broader societal impact. That potential distinction has a variety of ramifications. For example, should techniques developed for individual therapy automatically diffuse into the general public for purposes other than this therapy? Are physicians capable of restricting the use to one group, or docs societal pressure make them semiautomatic dispensers of secmingly desirable technologies?

Sixth, doesn't any eugenics program-whether it is positive or negative, voluntary or compulsory - imply a certain attitude toward "normalcy"; toward a proper norm for human activity and behavior; and toward expectations with regard to the behavior of future generations of human beings?

Seventh, how are words such as "normal," "abnormal," "health," "disease," and "improvement" defined? Are they words which can be operationally used to determine what should be done?

Eighth, we must ask if the quest for genetic improvement would be continuous. Would it invariably make all children "superior" to their parents? What would be the societal consequences of this? Would it institutionalize generation gaps and isolate communities by generations as education may have done?

Ninth, will the quest for genetic improvement of man lead to his perception of himself as lacking any worth in the state in which he is? What does this do to the concept of the dignity of man in his or her own right, regardlcss of some "index of performance"?

Tcnth, if we have a well-developed ability to perform genetic therapy and it is not available for all who have the affliction or who desire the "cure," how do we dctermine which patient will receivc the cure? Are some people more worthy of treatment? How will the selection be made?

While these considerations by no means exhaust the 
ethical realm, they do suggest the enormity of the problems with which we are attempting to deal. Perhaps the attempt-however primitive-at ethical classification might also offer the lawyer some general guidance. Let us examine the manner in which the American legal system is likely to deal with the subject. The issues raised by the technology of genetic therapy or engineering affect constitutional, statutory, and common law principles.

At least three constitutional factors clearly cmerge in considering the subject of genetic engineering. The first is the right to privacy. The fourth amendment to the Constitution declares that "the right of the people to be secure in their persons, houses, papers, and effects, against unreasonable searches and seizures, shall not be violated ..." This language has been interpreted to guarantee to the individual a constitutional right of privacy. This entire subject raises questions with regard to the extent and inviolability of that right.

Second, questions might be raised by the rights protected in the fifth and fourteenth amendments which guarantee that no person shall be deprived of life, liberty, or property, without due process of law.

Third, and perhaps the most important factor which the Constitution brings to bcar upon genetic engineering is the approach of constitutional law-the method of analysis which courts have developed for dealing with constitutional issues. Apart from technicalities inherent in whether state action is or is not involved, constitutional law requires the government to show a more compelling governmental need when abridgement of fundamental freedoms is involved. Contrast, for example, a governmentally sponsored compulsory program of negative eugenics designed to eliminate a certain genetic disease with a compulsory government program of positive eugenics designed to control behavior. As both programs would be compulsory, both could infringe the fundamental freedoms of procreation and possibly marriage. But a more compelling state interest could arguably be demonstrated in eliminating a disease than in controlling behavior. Constitutional analysis of the two approaches would bring different factors into being - and might yield different results.

Moving from constitutional to statutory law, it should be noted that a variety of statutes in numerous American jurisdictions have attempted to impose eugenics controls (primarily prohibition of marriage to certain classes of persons: criminals, alcoholics, imbeciles, the feebleminded, the insane, and persons with venereal disease). A number of more recent developments in the field of genetic engineering, however, go entirely unregulated. Sperm banks are an excellent example of an area in which statutes do not exist, an instance in which our third legal tier-common law-must be our guide. In the absence of constitutional and statutory guidance we must turn to common law for our standards. Here, again, the law is neither silent nor comprehensive. It falls somewhere in between. To the extent that current law is inadequate, legislation must be developed.

I do not believe that at this point in time it would be appropriate to suggest answers to the momentous issues that have been raised. But I do believe we know enough to undertake certain lcgislative initiatives. Let me suggest three.

First, the Congress should cnact the "Mondale Bill," providing for a study and evaluation of the ethical, social, and legal implications of advances in biomedical research and technology. This study could serve as a preliminary vehicle for educating the public into the foreseeable social consequences of biological advances.

Second, we should initiate technology assessment in all institutions which disburse funds, direct research, or provide grants which are related to biomedical concerns.

Third, it might be appropriate for the Congress to earmark a small portion of health research funds (say one-quarter or one-half of one percent) for research into the possible social consequences of biological technologies presently available or to be foreseen.

It should be evident that these potential legislative proposals include a common underlying thread-bringing science and socicty closer together. And this might be done in a varicty of other ways as well.

In an area as fraught with subjectivity as this one, it is important that the issues raiscd be aired. It is important to recognize that we are dealing with an area in which there is no monopoly of expertise. We are dealing with a subject in which morality or one's own subjective sense of ethics is pervasive. We are, therefore, dealing with an area in which all persons have a right and a special claim to be heard. 